\title{
Effectiveness of 'Jolly Phonics' Strategy in Developing the Pronunciation Skills of Primary Schoolers
}

By

Taghreed A. A. Mekawy

Prof. M. Abu-Rahmah

Dr. E. Albaaly

\section{Introduction}

According to Khamkhien (2010), English has increasingly become the medium of communication around the world both in global and many local contexts. Due to the importance of English, every country asks its people to become well equipped as for English performance.

Learning English language has become an important competence of living in a globalized world and this has in turn increased the importance of communicating with each other around the globe (Birch, 2007). This shows the need to integrate EFL pronunciation learning activities in the classrooms in order to give the student some situations that can develop their pronunciation by listening and speaking. Szynalski (2013) hints that it will be easy for people who listen to you to find out immediately whether your pronunciation is good or bad not as quickly as they notice whether or not you have limited vocabulary or bad grammar.

According to Gilakjani (2012: 119), EFL pronunciation has to be considered an integral part of learning a foreign language because it directly has an effect on learners' ability to communicate well as well as his performance.

Based on the researcher's experience as a teacher of English at Elewa Primary School in Al-sharqia, it was noticed that some pupils had difficulties in learning pronunciation. These problems lead to the lowering of the pupils' language performance. These difficulties might be a result of ineffective methods of teaching pronunciation that the teachers use at schools which affect pupils' learning.

Thus, the current study presents a new strategy 'Jolly phonics' which is a multi-sensory teaching involved which keeps children active and engaged in their language. Yellin et al., (2008) clarify that using Jolly phonics is helpful for pupils' achievement in learning through sound, movement and music. They confirmed that learning by being active in hands. On approach, pupils will retain more. 
Effectiveness of 'Jolly Phonics '------ Taghreed A. A. Mekawy

Prof/ M. Abu-Rahmah

Dr. E/ Albaaly

Lloyd and Wernham (2012), Perez (2014), Lodosa (2013) and Suarnajava (2018) state that Jolly phonics strategy is divided into five basic skills. These are:

1. Learning the letter sounds: Children are taught forty two main letter sounds.

2. learning letter formation: Using different multi-sensory methods, children learn how to form and write the letters.

3. Blending: Children are taught how to blend the sounds together to read and write new words.

4. Identifying the sounds in words: Listening for the sounds in words gives children the best start improving spelling.

5. Tricky words: Tricky words have irregular spelling and children learn these separately.

These skills are learned in a multi-sensory and fun way in Jolly phonics classes. These skills help children have a good mastery of letter sounds. This method includes materials and resources that seen to be very useful for both children and teachers.

Accordingly, the purpose of this study is to investigate the effectiveness of Jolly phonics strategy in developing the pronunciation skills of primary schoolers. The study seeks to answer the following three questions:

1. What are the English language pronunciation skills needed by the first year primary schoolers?

2. What are the features of some tasks and activities based on the jolly phonics strategy for developing the pronunciation skills of primary schoolers?

3. How far is the proposed strategy effective in developing these English pronunciation skills of primary schoolers?

Design of the study:

The quasi-experimental approach was adopted in this study. This study consisted of two groups' pre and posttest design. The reason for choosing this design was that the jolly phonics strategy was seen as new to the Egyptian context.

Sample of the study

The sample of this study included two first year primary classes from Elewa Elgededa Primary School in Sharqia Governorate at ElHuissanea directorate. One was the experimental group and the second as the control one. Each group consisted of $\mathbf{3 0}$ pupils. They were from 
the first year primary pupils. The experiment took place during the second term of the school year 2018-2019.

Instruments of the study

To achieve the purpose of this study, the following instrument was used:

1. A pronunciation skills questionnaire that aimed to identify the pronunciation skills appropriate for the first year primary pupils.

2. A pronunciation test.

The pre-posttest and the pronunciation skills questionnaire were valid after being submitted to ten TEFL specialists who reviewed both. Their comments were acted up to. The test and the pronunciation skills questionnaire were then valid.

Procedures of the study

After identifying the pronunciation skills prescribed for the first year primary pupils and the development of the test for assessing these skills, the following procedures were carried out:

1. A formal permission was obtained for conducting in the fieldwork. An orientation session in which the proposed learning materials was introduced. This included an idea about the pronunciation skills and the jolly phonics strategy.

2. The pronunciation skills pretest was applied in December to the study participants (two classes) from Elewa El-Gededa Primary School. One class was assigned as the experimental group while the other class was assigned as the control group.

3. After that, teaching the forty sessions began in February 2019 and continued for ten weeks at a rate of four sessions a week. Every session lasted for $\mathbf{3 0}$ minutes. Forty sessions dealt with jolly phonics strategy. Each session ended with a formative evaluation to evaluate the participants.

4. At the end of teaching, the posttest was administered. The data obtained were statistically analyzed, interpreted and connected to the previous studies as shown in chapter four.

Materials

The Jolly phonics strategy session materials used for developing the first year primary pupils' pronunciation skills (see Appendix 1)

Hypotheses of the Study

1. There are statistically significant differences at 0.5 level between the mean scores of the pre \& post measurements of the experimental group, in favour of the post-measurement. 
Effectiveness of 'Jolly Phonics '------ Taghreed A. A. Mekawy

Prof/ M. Abu-Rahmah

Dr. E/ Albaaly

2. There are statistically significances at 0.5 level between the mean scores of the post-measurement of the control and the experimental groups, in favour of the experimental group.

Results

After obtaining the pre-post-test results, an SPSS t-test and a practical significance equation were administered in order to assess the effectiveness of the program.

To answer question three which asks: How far is the proposed strategy effective in developing these English pronunciation skills? The answer can be deduced from the following hypotheses:

Results related to the first hypothesis

The following Table (1) shows the difference in mean scores of the experimental group on the pronunciation pre-post test.

Table (1)

t-Test of the experimental group for the pronunciation pre-post test

\begin{tabular}{|c|c|c|c|c|c|c|}
\hline $\begin{array}{l}\text { Experimental } \\
\text { Group }\end{array}$ & Mean & SD & t-value & df & significance & $\begin{array}{l}\text { Effect } \\
\text { size level }\end{array}$ \\
\hline $\begin{array}{l}\text { Pre } \\
\text { Post }\end{array}$ & $\begin{array}{l}0.70 \\
21.90\end{array}$ & $\begin{array}{l}0.988 \\
8.543\end{array}$ & 14.768 & 29 & 0.00 & $\begin{array}{l}0.88 \\
\text { high }\end{array}$ \\
\hline
\end{tabular}

As shown in Table (1), the t-Test reveals that the difference between the mean scores of the pre and post pronunciation test of the experimental group was statistically significant at 0.01 . All the differences are less than 0.01 , so there is a statistically difference between the mean score of the pre and post pronunciation test of the experimental group in favour of the posttest.

This result also, supports the findings of Albaaly (2014) which showed that jolly phonics strategy was effective for adults, but the present study showed that jolly phonics strategy was effective for young children not training teachers.

This result supports the findings of Ifeoma and Ibiam (2013) which showed that jolly phonics was effective in developing pupils' writing, but the current study aimed at developing pronunciation skills for primary schoolers.

It can be concluded that the proposed jolly phonics strategy is effective in developing English pronunciation skills among the primary schoolers.

Results related to the second hypothesis 
To compare the differences in mean score between the posttest for the control and experimental groups, the following table shows mean score, t-value, significance and effect size for both groups.

\section{Table (2)}

t-Test of the experimental \& control groups in the pronunciation posttest

\begin{tabular}{|l|l|l|l|l|l|l|}
\hline Group & Mean & SD & t-value & df & Significance & $\begin{array}{l}\text { Effect } \\
\text { size level }\end{array}$ \\
\hline Control & 2.80 & 2.041 & 11.910 & 58 & 0.00 & $\begin{array}{l}\text { 0.71 } \\
\text { high }\end{array}$ \\
\hline
\end{tabular}

As shown in Table (2) above, the t-test reveals that the difference between the mean score of the control group and experimental group in the pronunciation posttest was statistically significant at 0.01 . All the differences are less than 0.01 , so there is a statistically difference between the mean score of the control group and experimental group in the pronunciation posttest in favour of the experimental group. Therefore, it can be concluded that jolly phonics strategy was effective and improved the pronunciation skills.

At the two group level comparing between the posttest results of both groups, it was evident that the experimental group mean scores were higher.

This result is somewhat similar to what Lodosa (2013) reached. Lodosa's study proved that jolly phonics was effective in developing reading and writing skills for students. This result also agrees with what Suarnajava (2018) reached. The study investigated using jolly phonics strategy to improve children literacy.

It worth mentioning that, the effect size level is high in developing English pronunciation skills of primary schoolers. Such findings have proved that jolly phonics strategy has a positive effect on developing English pronunciation skills of primary schoolers. Thus, the hypotheses are verified.

To conclude, the results of the present study showed the study participants showed more improvement on the post application of the pronunciation skills test compared to the pre-application whether at the experimental posttest group level or at the experimental control posttest level. It can be concluded that the proposed strategy based on jolly phonics is useful and effective in developing English pronunciation skills among the primary schoolers for the following reasons:

1. It facilitated better understanding of relationships and connections between letters of English and their sounds. 
Effectiveness of 'Jolly Phonics '------ Taghreed A. A. Mekawy

Prof/ M. Abu-Rahmah

Dr. E/ Albaaly

2. It helped pupils to deal with activities of different levels of difficulty which enhanced their confidence to pronounce fluently as shown in their posttest performance.

3. It helped pupils' motivation towards Learning English pronunciation.

4. It helped pupils to pronounce words correctly.

5. It helped pupils to hear English and understand correctly.

6. It made pupils happy to learn English.

7. Its activities helped pupils practice a lot to improve their pronunciation skills.

8. It helped pupils to be co-operative and active.

Recommendations

Based on the findings and conclusions of the current study, it is recommended that

1. Teachers of EFL should encourage their pupils to use jolly phonics in learning pronunciation skills to develop their language performance.

2. Teachers of EFL should encourage their pupils to use jolly phonics in learning pronunciation skills to enhance their language understanding.

3. EFL students should be trained on designing and using the different types of Jolly phonics activities appropriate for primary stage pupils.

4. Jolly phonics strategy should be an integrate part of the teaching methods recommended for Teaching English at the primary curriculum of English in different stages.

5. EFL teachers should be trained on the use of Jolly phonics strategy to improve their teaching in a way that helps young learners develop their pronunciation skills.

\section{References}

Albaaly, E. (2015). A 'Jolly Phonics' Based Training Program for EFL Teachers of Young Learners. Menofia Journal of Arab Studies in Education and Psychology, 59 (2)

Birch, B. (2007). English L2 Reading Getting to the Bottom, $2^{\text {nd }}$ ed. USA:

Lawrence Erlbaum associates, Inc.

Gilakjani, A. (2012). A Study of Factors Affecting EFL Learners' English Pronunciation Learning and the Strategies for Instruction. International Journal of Humanities and Social Science. 2 (3). 
Ifeoma, O. and Ibiam, J. (2013). The efficacy of jolly phonics instructional strategy on the writing ability of junior primary pupils' in Uyo senatorial district of Akwa Ibom State, Nigeria. Merit Research Journal of Education and Review. (1) 9

Khamkhien, A (2010). Thai Learners' English Pronunciation Competence: Lesson Learned from Word Stress Assignment. Journal of Language Teaching and Research, (1) 6, (757-764).

Lodosa, A. (2013). Jolly Phonics: How Teachers can Teach Reading and Writing to their Students. Universidad Publica De Navarra Nafarroako Unibertsitate Publikoa.

Lloyd, S. and Wernham, S. (2012). The phonics handbook: A handbook for teaching reading, writing and spelling. $\left(4^{\text {th }}\right)$ Jolly Learning Ltd. Chigwell, England.

Perez, A. (2014). Jolly Phonics: A method to teach English Reading and Writing in Preschool.

Suarnajava, I. (2018). Jolly phonics: Effective strategy for enhancing children English literacy. Retrieved for:

https://www.researchgate.net/scientific-tributions/2138343823

Szynalski, T. (2013). Why you should study English pronunciation. Retrieved for: http://www.antimoon.com/how/pronuncwhy.htm 


\begin{abstract}
The aim of this study was to investigate the effectiveness of Jolly phonics strategy in developing English pronunciation skills of the first year primary pupils. The study adopted the two groups' pre and posttest design. In this design, the dependent variable was measured before and after the experiment. The sample of this study included two classes from Elewa Elgededa Primary School in Sharqia Governorate in El-Huissenea directorate. One was the experimental group and the second was the control one. Each group consisted of 30 pupils. The experimental group was taught adopting jolly phonics strategy for learning pronunciation skills, whereas the control group was taught using the textbook. The instrument was an EFL pronunciation test. It was administered to both groups before and after the treatment. The data obtained was analyzed statistically through the use of Cronbach's Alpha, t-test and Eta-squared. The findings of the study revealed that the pronunciation skills of the participants were developed as a result of the jolly phonics strategy. Therefore, it can be concluded that jolly phonics strategy is effective in developing the EFL pronunciation skills among the primary stage pupils.
\end{abstract}

Key words: Jolly phonic, EFL pronunciation skills, primary school pupils.

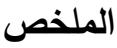

الهدف من هذه الاراسة هو معرفة مدى فاعلية استراتيجية "جولي" للصوتيات في تنمية مهارات نطق اللغة الإنجليزية لاى تلاميذ الصف الأول الابتدائي. اعتمدت الدراسة تصميم الاختبارين القبلي والبعدي فئي

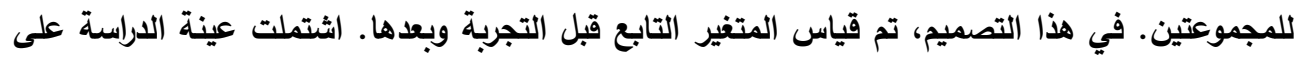
فصلين من مدرسة عليوة الجديدة الابتدائية بمحافظة الثرقية بمديرية الحيسينية. كانت الأولى المجموعة الجئه

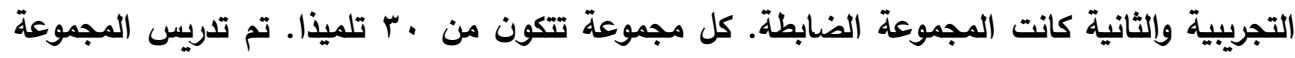

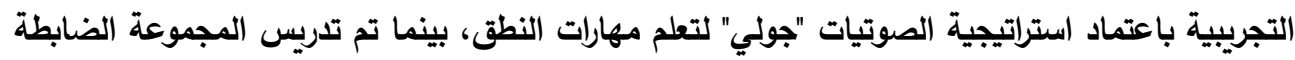
باستخدام الكتاب المدرسي. كانت الأداة عبارة عن اختبار نطق اللغة الإنجليزية كلغة أجنبية. تم إعطاؤه

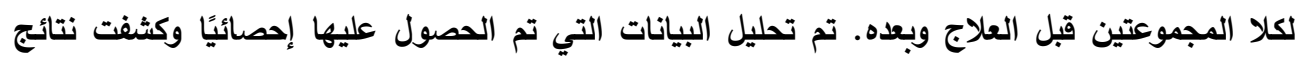
الدراسة أن مهارات النطق لاى المشاركين تم تطويرها نتيجة لاستخدام استراتيجية "جولي" الصوتيات. لذلك، يمكن استنتاج أن إستراتيجية "جولي" للصوتيات فعالة في تطوير مهارات نطق اللغة الإنجليزية كلغة أجنبية بين تلاميذ المرحلة الابتدائية.

الكلمات المفتاحية: جولي فونيك ، مهارات نطق اللغة الإنجليزية كلغة أجنبية ، تلاميذ المرحلة الابتدائية 